\title{
PINTÉR RÓBERT
}

\section{Ki felelős a bünbeesésért?}

\section{Szerzői információ:}

O P in tér Róbert

1999-ben diplomázott az Eötvös Loránd Tùdományegyetem szociológia és 2000-ben a politológia szakán, jelenleg ugyanitt a szociológia $\mathrm{PhD}$ fokozat megszerzése elốtt áll. Megalapítása óta a BME-UNESCO Információs Társadalom- és Trendkutató Központ (ITTK) kutatója, 2001 januárjától a Budapesti Mû́szaki és Gazdaságtudományi Egyetem (BMGE) Információ- és Tudásmenedzsment tanszéknek tanársegédje, több felsôfokú intézmény óraadó tanára. Fố kutatási témája az információs társadalom, ezen belül elsôsorban az információs politika-stratégia; az Európai Unió információs fejlődése; a finn információs társadalom; a (média)konvergencia; és az információs társadalom, mint kockázattársadalom.

Így hivatkozzon erre a cikkre:

Pintér Róbert. „Ki felelős a bűnbeesésért?”.

Információs Társadalom IV, 3-4. szám (2004): 26-36.

https://dx.doi.org/10.22503/inftars.IV.2004.3-4.4

A folyóiratban közölt müvek

a Creative Commons Nevezd meg! - Ne add el! - Így add tovább! 4.0

Nemzetközi Licenc feltételeinek megfelelően használhatók. 
Pintér Róber $\mathrm{t}$ :

Ki felelős a bûnbeesésért?

\section{A pozíció}

„Nekem az a bajom a zöldmozgalommal, hogy - mint minden forradalom és minden avantgárd - idővel dogmatikussá válik. Kialakulásakor friss, dinamikus, haladó, majd amikor intézményesül, kezdődik az agymerevedés, ragaszkodás a dogmákhoz, a nem ésszerû, hanem automatikus reagálás minden kihívásra" - írja Görgey Gábor a Figyelő hasábjain (Görgey, 2004). Mélységesen egyetértek Görgeyvel, és ahogy itt ülök Sükösd Miklós cikke felett, azon gondolkodom, hogy vajon friss, dinamikus, haladó, vagy agymerevedett, dogmatikus, ésszerûtlen és automatikus reagálásokkal teli írásról van-e inkább szó. Mint mindig, ezúttal is hajlok az is-is felé - valamirevaló posztmodern szociológus szerintem nem is tehet másként. Sükösd cikkében ugyanis egyszerre rettent el a pártosság és a felületesség, illetve ragad magával némely gondolatának újdonsága.

Amikor Miklós még megjelenés előtt megmutatta nekem a cikkét, alaposan kipingáltam egy példányát, így a következőkben, pontról-pontra követem a sükösdi gondolatmenetet, és a cikkhez két hónapja írt, néhol talán összefüggéstelen gondolattöredékeket veszem sorba, hogy nyomára bukkanjak a fentebb vázolt kettősség okainak. Megpróbálom tehát a saját nézőpontomból, inkább esszészerűen, mint tanulmány formában megvilágítani, hogy miért éreztem magam egyszerre elégedetlennek, indulatosnak és izgatottnak, amikor a cikket először olvastam.

\section{Lenulláz a mottó}

Kezdjük mindjárt a cikk előtt álló idézetekkel, amelyek számomra remek módon példázzák a gondolatrestséget, a dogmatikusságot és a meg nem engedhetô túlzásokat.

Ha cinikus volnék, azt mondanám, hogy ha már világvége-hangulatú, „tévéellenes” idézetek vannak a szöveg elején, szerintem Baudrillard-t kár volt kihagyni, hiszen részben mintegy az ô köpenyébôl bújtak elő az idézett szerzốk. Baudrillard-nak fantasztikusan érdekes és eredeti gondolatai vannak a témával kapcsolatban, például A rossz tranšparenciája címú, magyarul is megjelent könyvében. Az alábbi idézet azonban nem ebből, hanem a Ligetből, tehát a humánökológiai gondolat hazai fellegvárából származik, ahol az idézett szerzốk (Lányi András és Karátson Gábor) is gyakorta publikálnak: 
„Az emberek azért ábrándoznak eredeti és zseniális gépekről, mert nem bíznak többé saját eredetiségükben, vagy mert szívesen lemondanak róla, hogy gépek közbeiktatásával birtokolják. Mert amit ezek a gépek nyújtanak, az a gondolkodás mutatványa, és a gépeket kezelő emberek sokkal inkább a gondolkodás mutatványának, mintsem a gondolkodásnak adják át magukat.

Nem hiába nevezzük ezt a gondolkodást virtuálisnak: egy tökéletes, kimerító tudás feltevéséhez kötôdik, amely bizonytalan függôségben tartja. A gondolkodás aktusa ettől végtelenül különböző. A gondolkodás képességét fel sem lehet vetni többé, mint ahogy a szabadság kérdése is értelmetlen a jövendô generációk számára: úgy fogják átszelni az életet, mint valami légteret, ülésükhöz rögzítve. A Mesterséges Intelligencia Emberei is így szelik majd át mentális terüket, komputerükhöz láncolva. A Virtuális Ember - számítógépe előtt, mozdulatlanul - a képernyôn át szeretkezik, és távkonferenciákon tart előadást. Testi, és kétségtelenül szellemi nyomorékká válik. Ezen az áron múködőképes. Ahogy előre látható, hogy egy nap a szemüveg vagy a kontaktlencse szerves tartozéka lesz a fajnak, mely látását elvesztette, ugyanígy félő, hogy a mesterséges intelligencia és technika hordozói is a protézis szerepét fogják betölteni a fajnál, amelyből a gondolkodás kiveszett." (Baudrillard, 1994: 47).

Szerintem ez a baudrillardi eszmefuttatás már csak azért is találóbb mottó lehetett volna Sükösd cikke elé, mert nem a televízióról, hanem arról a jövőről szól, ahol a teljes virtualitás, a világtól (természettől) való elmenekülés már valóság - vagy pontosabban, már A Valóság.

De térjünk vissza a humánökológusok televízió-képéhez. Az az érzésem, hogy a mottóul választott szövegek a televíziót és az új médiát elsősorban nem tudományos alapon utasítják el, hanem inkább érzések, érzékletes képek és értéktelített víziók mentén. Természetesen a Sátán azonosítását a médiával nagyon érdekes és fontos meggyőződésnek tekintem, de hittételnek, ami nem az igaz/hamis, hanem a jó/gonosz (és így a hiszem/nem hiszem) kategóriapárral ragadható meg igazán. Tudományosan pedig nem lehet vitatkozni róluk. Vagy elhiszem, elfogadom, amit Lányi és Karátson ír, vagy nem hiszem el. (Csak a dolgok tisztánlátása érdekében, én inkább nem hiszem el.) Elhibázottnak tartom tehát Sükösd azon lépését, hogy egy fontos érvrendszert bemutatni kívánó tudományos cikk mottójául ilyen idézeteket választott, (sőt, úgy tûnik komolyan is vette ôket), számomra ugyanis ezzel már a cikk elején átlépte a tudományosság határait, olyan eszközrendszert választva magának, amelyet nem tudok tudományos értelemben értelmezni, sem komolyan venni, így javarészt előre érvénytelenítette mondandóját.

Egyébként, ha már mindenféleképpen muszáj volna kidobnom a tévét az ablakon, sokkal inkább egyetértek a feldühödött foci-vb rajongóval, aki csapatában csalódva vágja ki a készüléket a szemétre - vagy, a viccet félretéve, Csíkszentmihályival, aki az elpazarolt szabadidő, kreativitás és elpocsékolt pszichikai energiák okán veti el az elektronikus médiát (Csíkszentmihályi, 1997:229) és nem azért, mert az a Sátán kutyaólja. 


\section{Feketén-fehéren odakenve (Bevezetés)}

Sükösd hipotézise, hogy „kapcsolat áll fenn két látszólag távoli jelenségcsoport, a mai nyugati társadalmak mediatizációja (médiával való áthatottsága, átitatottsága, mediális léte, az információs társadalom kialakulása), és a globális ökológiai válság (az ökocídium, a természeti környezet kiirtásának folyamata) között.” Ez a kiinduló, összegzô hipotézis alkalmat ad arra, hogy megfogalmazzam a saját meglátásom összegzését Sükösd gondolatmenetével kapcsolatban. Jellemző ugyanis - nemcsak erre az egy állításra, hanem a cikk egészére, ahogy azt később látni fogjuk -, hogy összemos nem egészen azonos, de rokonítható jelenségeket. Például a használt fogalmak (a nyugati társadalmak médiával való áthatottsága-átitatottsága, mediális léte, és az információs társadalom) egyszerú szinonimák? A felsorolás azt indikálja, hogy a medialitás és az információs társadalom tulajdonképpen ugyanaz. Websternek van egy cikke (Webster, 1995), ahol öt információs társadalmi megközelítést különít el, melyek közül az utolsó a kulturális (medialitásra építő), a többi azonban másra koncentrál. Én sem szúkíteném az információs társadalmat csupán erre. Az információs társadalom ez is, de nem csak ez.

Az összemosáshoz szorosan kapcsolódva a cikkel kapcsolatos másik általános jellegû́ meglátásom - amit előrebocsátásképpen fontos megjegyezni -, hogy számomra Sükösd írása vagy-vagy jelleggel láttatja a folyamatokat, feketén-fehéren mutatja be a témát, és elfelejti az árnyalatokat, így a „szürke” zónájába tartozó, de a témához szorosan kapcsolódó dolgokról elôszeretettel nem tesz említést. (Ez egyébként nem egyedül Sükösdöt, hanem azt a gondolati iskolát egészében is jellemzi, amelyből mottót választott - előbb harapnák le a nyelvüket, mint hogy elismernék, hogy például a televízióban van valami jó.) Például visszatérve a cikk központi hipotéziséhez: Sükösd elég merész állításként oksági kapcsolatot tételez fel a média és az ökológiai válság elmélyülése között. „A globális fogyasztói kapitalizmus és az ökológiai válság között tehát oksági viszony áll fenn: a fogyasztói kapitalizmus mai rendszere fenntarthatatlan, elterjedése ökológiai válsághoz vezet.” Már ennél a kiindulópontnál elsikkad azonban az árnyalás, vagyis, hogy bár az így létrejövő kockázattársadalom egyben információs társadalom is, de nem csak az, tehát nem feltétlenül csak és kizárólag negatív hatásai vannak. Itt azonban még az árnyalás ellenére gyakorlatilag ugyanazt mondjuk, csak kicsit másképpen (ld. Pintér, 2003). Egyetértek Sükösddel abban is, hogy „[a] média hírműsoraiban, napirendjében háttérbe szorul a környezeti válság témaköre”. Vagy ha meg is jelenik, akkor klisék, sztereotípiák mentén, felszínesen, lerágott csontként, mínuszos hírként - ami részben a hírgyártás ipari logikájából következik. Az azonban szerintem „természetes” folyamat, hogy „egyre kevesebb elsődleges élményünk van természeti környezetünkről”, ugyanis az emberiség tudásának egyre nagyobb hányada konszenzuális és nem tapasztalati. Ez azonban nem jelenti egyúttal azt is, hogy most kevesebbet tudnánk a természetről, mint amikor még a természetben éltünk, vagy a természetben élés a priori elôrébbvalóbb volna, mint a természeten kívüli (társadalmi), de erről alant szólok bővebben. 


\section{Letelepedési engedély Médiába (Média-téridő, média-valóság)}

„A mediatizáció és az ökológiai válság összefüggésére utaló elsô érv szerint a média terében töltött idő egyszerűen elvonja az ember tudatát, figyelmét, reflexióit a valóságos téridôtôl." Sükösd azt feltételezi, hogy a média tere nem része a valóságos téridőnek, nem valóság, vagy legalábbis, kevésbé valóság. Talán kevésbé értékes is? Szerintem azonban ez nehéz filozófiai kérdés, mert mi is a valóság? A valóságosnál is valóságosabb valóság van-e? És mi a valóság, ha nem társadalmilag konstruált, közvetített? Ez a kérdés tehát nem olyan egyszerû, mint amilyennek látszik - szerintem elkelne itt egy alapos filozófiai tisztázás, amihez azonban a magam szociológiai képzettségével nincs megfelelő eszköztáram, viszont jelezném, hogy ez a kiindulópont szerintem problematikus.

De lépjünk túl ezen a feltevésen. Sükösd következő állítása, hogy ebben a nem valóságos téridőben, a média valóságában töltik az emberek a szabadidejük túlnyomó részét: „[a] televíziónézésre jelenleg a 15-74 éves férfiak 2 óra 40 percet, a nôk 2 óra 30 percet fordítanak naponta átlagosan. Mennyiségében és arányában is egyre kevesebb a televíziónézésen kívüli szabadidő.” Az állítással általában egyetérthetünk, de óvatosan kellene bánni azzal, hogy mindenkire egyaránt ugyanennyit szignálunk. A WIP adatai szerint legalább öt társadalmi csoport különíthetố el a médiafogyasztása (televízió, rádió, olvasás, zene, telefon) alapján (Pintér, 2003). Ugyanebben az elemzésben látható, hogy az átlagos tévénéző mint olyan, nem értelmezhetô a társadalom egészében, a társadalomnak nagyjából a fele mondható „átlagosnak", a másik fele négy csoportba osztható, és sokan vannak, akik szinte nem is néznek televíziót, míg egy 2\%-os kisebbségi csoport „médiazabáló” úgy tapad a különböző készülékekre, mintha teljesítménybérben fogyasztaná a médiát. Az átlag tehát - feltéve, hogy értelmezhetố - valójában a fentiétôl alacsonyabb adat a társadalom felében, a többinél meg jelentősen eltér az átlagostól. ${ }^{1}$

A valóság fogalmának pontatlan megragadása és az átlagokkal való ,játék” azonban csak a kisebbik gond, a nagyobbik a következtetés, ami utánuk jön: „[h]a médiát használunk, például tévét nézünk vagy internetezünk, akkor médiaélménybe merülünk. Tưdatunk, figyelmünk jelentôs része nem a valóságos természeti vagy épített környezet terébe, hanem a médiatérbe hatol. Minél inkább a média tartalmára, az ott adott tárgyra figyelünk, annál inkább a médiatérben időzik a tudatunk. A médiatérben töltött idő aránya pedig egyre nő a nap 24 órájában, és összességében egész életünkben. Tudatunk egyre inkább a médiavalóságba húzódik, egyre több idôt tölt a média- és kibertérben, és egyre kevesebbet a valós téridőben." Nekem itt nagyon úgy tûnik, hogy Sükösd értékítéletet mond, bújtatva azt állítja, hogy a valóság (a természet) jó, a média (a nem valóság?) pedig rossz. Arra azonban nem kapunk magyarázatot, hogy miért tartsuk értékesebbnek a valóságban töltött idốt a médiával töltöttnél. Ez egy olyan kulturális előfeltevés, amit szerintem érdemes volna

\footnotetext{
' Érdemes volna még az új média idốháztartásra gyakorolt szerepével is foglalkozni egy kicsit. Míg a tévé tevékenységhelyettesítô (szakterminussal kifejezve ez a time-displacement), addig az Internet a vizsgálatok alapján inkább tevékenységszervezô (lásd pl. Robinson és munkatársai írásait az Internet and Society címû folyóirat 2002 őszi, tematikusan ezzel a kérdéssel foglalkozó lapszámában. IT, Mass Media and Other Daily Activity: http://www.stanford. edu/group/siqss/itandsociety/v01i02.html
} 
megvizsgálni és bevonni az elemzésbe. Vannak, akik - mint például én - nem értenek maradéktalanul egyet ezzel a kiinduló premisszával. Nem tudok azonosulni azzal, hogy a „médiatérbe helyezett tudat eltávolodik az elsôdleges környezettôl”. Én inkább azt állítanám, hogy kevesebbet érintkezik vele közvetlenül, és ez megváltoztatja a vele való viszonyát, de nem feltétlenül távolít el mindenkit. Ha mindenkit eltávolítana, akkor nem is foglalkoznánk az ökológiai válsággal, és nem vitáznánk most róla.

\section{Húzzuk be a függönyt, ha tévézünk! (Média-élmények)}

„Tapasztalat kontra információ: hús-vér, tapasztalati valóságunkkal szemben fontos élményeink egyre inkább a mediális valóságból származnak, technológiai médiumok közvetítette vizuális, auditív és szövegalapú információként dolgozzuk fel őket.” Ahogy azt már említettem a bevezető részben, ezzel az állítással és implikációival nem teljesen értek egyet. Sőt, a tapasztalati úton megszerzett tudás és a konszenzuális tudás közötti feloldhatatlan ellentmondásra, az előbbi elsődlegességére építố elgondolásokat bántóan leegyszerúsítőnek találom. Szerintem régen sem minden tudást közvetlen tapasztalati úton szereztek meg az emberek. Nem hiszem azt sem, hogy mindig értékesebb a közvetlenül szerzett tudás a közvetve szerzettel szemben, ami másodlagos és kárhoztatott (ez is vitatható értékítélet). Másrészt nem az a baj, hogy a közvetve megszerzett tudás mennyisége megnő, hiszen mi jóval többet tudhatunk meg így a világról, mint bármelyik elődünk. A probléma sokkal inkább az lehetne, hogy a figyelem tárgya egyre kevésbé a természet. Erről azonban itt (még) szó nincs.

És nem értek egyet a következő állítással sem: „[a] valós téridőtől való elvonás ugyanakkor egyfajta ökológiai deficitet okoz. Egyre kevésbé vagyunk kíváncsiak a valódi érzékekkel érzékelhetô élményre, az ökológiai válság jeleire. Napi több órát nézzük a tévét - a tévében mondjuk a Survivor Dominikán forgatott epizódjait, vagy internetezünk házunkban, amely a vegyszerektôl bủzlő, halott patak partján áll. Az utóbbira nem vagyunk kíváncsiak.” A „not-in-my-backyard” ( „ne az én kertembe”) jellegư mozgalmak éppenséggel pont arról szólnak, hogy sokan, akiket nem érdekel az egész ökocídium, arra nagyon érzékenyek, hogy a közvetlen környezetükben semmi káros ne legyen (néhány kilométerrel odébb már lehet, csak ne lássák, és ne legyen rájuk kézzelfogható hatással).

Arról van tehát szó, hogy nem egyértelmû, egyetlen irányba mutató „hanyatlásról” van szó a médiaélmények hatására: a helyzet rossz, de nem mondható el mindenkirôl, aki médiát fogyaszt, hogy közönyös. Olyan túlzó állításrendszer ez, amely tarthatatlan a társadalomban tapasztalható sokszínú reakciókat tekintve. Ismét csak hiányzik tehát az árnyaltság. 


\section{A média beszél belőlünk (Média-(napi)rend)}

„A tévé- és rádiómûsorok, az újságok tematikája befolyásolja a közfelfogás, a közvélemény témáit [...] a média azonban általában nem tartja fontosnak a környezeti napirendet [...] músorai a reklámokhoz kívánnak minél nagyobb és gazdagabb nézősereget verbuválni. Ezért a szórakoztató műfajok dominálnak a műsorfolyamban" - mondja Sükösd. Ez azonban hibás logika. Az agenda setting (mzzzzzzédia-napirend) funkció egyértelmúen nem a szórakoztató mûsorokhoz, hanem inkább a hírmúsorokhoz köthetô, még ha az igaz is, hogy szórakoztatni kíván (infotainment). És a média e téren nem is bír teljhatalommal. Ez onnan is látható, hogy a híradók közel azonos híreket mutatnak napról-napra, tehát bár meghatározzák, mit adnak le, sokszor nem tehetik meg, hogy bizonyos dolgokat nem adnak le, amik történnek.

Ettől persze a kérdés még megmarad: miért nem fontos, miért nem jelenik meg az ökológiai válság a képernyőn? Egyrészt álságosnak érzem azonban ezt kizárólag a médiára és az igénytelen nézốkre fogni. Csupán a média hibája ez? Másrészt pedig a média perverz logikáját ismerő zöld csoportok mégiscsak meg tudnak jelenni, ez is érdekes jelenség, amivel Sükösd nem számol: Greenpeace, Zengő-hegyi tiltakozás stb.. Érdemes volna tehát elemezni, hogy ami mégis megjelenik a mainstream-ben mint hír a környezetről, az vajon hogyan képes ezt megtenni. A hipotézisem az, hogy eleve a média számára csomagolják. Így napirend-meghatározó funkciója ellenére sem teheti meg a média, hogy ne vezetố helyen hozza ôket.

\section{A tévében zöldellő fákról álmodom (Média-narratívák)}

A valóságról egyre inkább a médián keresztül szerzünk tudomást, így a valóság helyére lassacskán a média által szerkesztett kép kerül, mondhatnánk. A kérdés ezzel kapcsolatban számomra az, hogy van-e ennek alternatívája? Lehetne-e ez környezettudatosabb folyamat? (Amit hiányolok nemcsak Sükösd cikkéből, hanem például az egész humánökológiai irányzatból, az az alternatívák nyújtása. A „ne így” mellett annak megfogalmazása, hogy „akkor hogyan”. Nem vagyok mohó, nem egy teljes rendszer leírására vágyom, ami felválthatná a mostani ördögit, beérném kevesebbel is.) Mit csináljunk a médiával? Mit csináljunk a világgal? Hogyan szerezhetünk információt és tudást, híreket a világból? Ez a kérdés felvetôdik az egyén, a közösség, a társadalom és az emberiség szintjén egyaránt. Elvárnék egy koherens és fenntartható (életszerû), a médiára vonatkozó iránymutatást a humánökológiai oldalról.

A fejezet további részeiben a már többször említett árnyaltságot kérném számon:

1. A természet-kép sivár: Szerintem elképzelhető, hogy nem mindenhol azonos a természetszemlélet. A finnekról például tudom, hogy imádnak a természetbe járni, az ottani álom egy tóparti kis hétvégi faházacska (mökki), ahol még áram sincsen, csak csend és nyugalom...

2. A természet megtapasztalása leszúkül: Mennyivel többet tudhat meg a médiából egy átlagember a természe tről, az állatokról, az etológiáról! Az átlag- 
elôdök nem tudták ilyen közelrôl meglesni az állatokat, mint mi, most. ${ }^{3} \mathrm{Ez}$ akár jó is lehetne a természetnek. Az érdekes, hogy az így megszerzett tudás ellenére miért nem lesz környezettudatosabb az ember.

3. Csak a médiasztár-állatok kapnak teret: Egyszer láttam a tengeri csillagokról egy megkapó filmet (ezek meglehetôsen lassan mozgó, médiaszempontból „unalmas” élőlények), de aztán egy filmes rájött, hogy fel kell gyorsítani a felvételeket, mert ők egy lassúbb idődimenzióban élnek. Itt is megjelenik persze az emberi világhoz való idomulás mozzanata, de aztán tényleg hihetetlenül érdekes lett a film, pedig nem valami televízióra termett állatokról van szó. Vagyis lehet ezúttal is ellenpéldát találni arra, hogy csak az izgalmas médiasztár-állatok jelennének meg a képernyőn, bár tudom, egy példa nem példa.

4. Az állatok antropomorf ábrázolásban jelennek meg: Ellenpélda: a Fecsegố tipegőkben nem beszél a kutya, sőt egészen kutyaszerü, az egyik egész estés epizódban például elcsavarog egy kutyalány miatt. Egyébként az állatok antropomorfizálása egyáltalán nem új keletû (ld. totemek), ezt sem „fognám” tehát a médiára, mint alapvető bưnt. Nem a médiában, hanem az emberi természetben kell keresni az antropomorf ábrázolás okait.

5. A felnövekvô nemzedék antropomorf, rajzfilmes természetképpel rendelkezik: Látva a családban a másfél éves Bence unokaöcsémet, az állatok nagyon fontosak számára, beszélni még nem igazán tud, de állathangokat utánozni már igen. Érdeklődik irántuk, a szülei pedig rajzolnak neki, könyvekből mutogatják, rendszeresen viszik állatkertbe. A kisgyermekek sokszor „állatbarátok”, kérdés, mi történik velük, hogyan nőnek fel.

6. Az ökológiai válság nem jelenik meg a képernyôn: A feltételezéssel ellentétben készülnek az ökológiai válsággal foglalkozó filmek is. Paradox volna azt állítani, hogy ezekről nem a médián keresztül szerzünk tudomást, amikor szinte mindenrôl abból tájékozódunk. Vannak ilyen filmek, vannak ilyen információk, de elsôsorban nem a kereskedelmi médiumokban, mert azok bulvár-logikájától ez távol áll. Például az „ipari bálnavadászatról mikor láttunk dokumentumfilmet?" kérdezi Sükösd. Jómagam már láttam ilyen filmet, léteznek, csak éppen nem a kereskedelmi adón, fố mưsoridőben adják le ôket, mint ahogy sok minden nem kerül ebben az idősávban adásba - nem csak a természet.

7. A társadalmi szenvedés nem jelenik meg a mainstream médiában: Egyrészt ez nem az ökológiai ökocídium, hanem valami más (még ha kapcsolódik is hozzá), másrészt ezek igenis megjelennek a médiában, nap-nap után, sôt, egyre véresebb képekben. A baj itt sokkal inkább az, hogy ez öncélúvá válik, a hírek nem magyaráznak, nem helyeznek kontextusba, nem mérlegelnek, hanem "szórakoztatnak" és sokkolnak (mert más médiatartalmakkal versenyeznek a nézettségért).

8. Az ökocídium társadalmi következményei nem kapnak teret: Bár a szórakoztató tömegmédiában a téma nem jelenik meg (leszámítva a 7. pont alatt mondottakat), a médiában máshol megjelenik.

\footnotetext{
${ }^{3}$ Személyes kedvencem a Pig Brother: az Interneten egész álló nap nyomon követhetố a német Harzhegységben élố vaddisznócsalád élete két webkamera segítségével (http://www.wildtiere-live.de/)
} 
$\mathrm{Az}$ ellenvetések ellenére kétségtelen persze, hogy a „természetfilmek látványos, hangos drámáihoz, a rajzfilmek vidám, digitális forgatagához képest lassú és unalmas az igazi, kopott erdő.” A természet nem tud felgyorsulni a jelenlegi társadalmi tempóhoz, mindez hozzájárul a természettôl való elforduláshoz. Probléma marad ugyanakkor, hogy ennek alapján nem magyarázható a társadalomban élốk reakcióinak sokszínúsége: miért lesz az ugyanabban a nem-valóságos média- környezetben élő egyik emberből zöld, a másikból pedig közönyös. Ezt akkor lehetne megmagyarázni, ha nem egyértelmúen fekete-fehérben látnánk ezeket a jelenségeket. Ehhez azonban kiindulásként fontos lett volna tipizálni a médiát valahol a cikk elején, hogy általában melyik/milyen médiáról beszélünk, melyikre mi jellemző. Érzésem szerint Sükösd állításai kevés kivételtôl eltekintve a legnézettebb kereskedelmi tévéadásokról szólnak - ezek azonban egészen biztosan nem jelentik a média egészét. Így azonban hamis képet kapunk a médiáról.

\section{A fogyasztó a termék (Médiaboldogság: reklám és az anyagi fogyasztás élvezete)}

„[A] szerkesztett médiatartalom - a szórakoztató és hírmûsorok - feladata, hogy a megfelelő nagyságú és összetételû célközönséget a reklám elé vezesse.” Szerintem itt is árnyalni kell a kiindulópontot: a kereskedelmi média célja a profittermelés, aminek manapság a reklám jelenti a legfóbb forrását, de nem kizárólagos, van ott más is, amiből pénzt tudnak csinálni (pl. amikor egy mûsor állami forrásból pénzt nyer pályázaton), másrészt van másfajta modell is (pl. előfizetéses).

Ugyancsak nem teljesen új a reklámokban megfogható életstílus-kommunikációs elem. Életstílus-kommunikációk minden közösségben léteztek (ha nem is reklámok), bár az tény, hogy napjainkban elburjánzottak és felszínesebbek. A divat, a mintakövetés ugyanakkor fontos társadalmi funkciót tölt be, az archaikus közösségekben is meglepốen sok tevékenységnek a látens célja összetartani a közösséget, szerintem részben ilyen a ma társadalmában a reklám is, nem ítélném hát el teljesen a totális medialitás kritikájának oltárán. Azzal azonban maradéktalanul egyetértek, hogy a reklámok egészen torz értékszemléletet tudnak közvetíteni.

\section{Halak a dobozban (Médiatrend: vándorlás a digitális uni- verzumba)}

„A médiatörténelem trendje tehát az, hogy a médiumok az érzéki tapasztalat pótlására egyre átfogóbb mûvi pótlékokat nyújtanak. A sort a virtuális valóság (VR) teljesíti be. A VR újdonsága, hogy a maszk felvételekor a digitális univerzumot immár három dimenzióban érzékeljük és - a kezünkre, testünkre erősített érzékelőkkel manipulálhatjuk." Mielőtt messzemenő következtetéseket vonnánk le a VR-rel kapcsolatban, ne felejtsük el, hogy a VR nem elterjedt, nem lehet egy sorban említeni a könyvvel vagy a tévével, a VR-ról szóló elképzelések merő spekulációk jelenlegi formájukban. Nem tudni ugyanis igazán, hogy a dolog hogyan, milyen formában és mikor terjed el, ha egyáltalán sor kerül erre! 
Számomra nagyon fontos pont ez, mert Sükösd itt nemcsak egy tudományos elemzés vagy egy kötetlenebb tudományos esszé kereteit hagyja el, hanem a mottóul választott idézetek mintájára szépirodalmat kezd el írni: „Miközben a nyugati emberiség fokozatosan átvándorol a digitális univerzumba, odakint lassan elfogy a valóság, mint a fuldokló levegôje, vagy a friss víz az akváriumból a halnak.” Innentôl kicsit bátortalanná válok, ez az írás esszének túl tudományos, tudományos cikknek viszont túl esszészerû.

\section{Rajzoli nekem egy bárányt! ( $($ ( z élő)hely lerombolása)}

Bár itt már jócskán a cikk végén járunk, továbbra sem kaptam teljesen kielégítő magyarázatot arra, miért baj, hogy a média „a hagyományos itt és mosttól eltérő élménystruktúrát kínál." Nem ad magyarázatot az sem, hogy Sükösd bevezeti a genius loci fogalmát: „[a] kommunikáció helynélkülisége elsöpri a helyi szituációval értelmessé rendeződő helyet, az aurával körbevett genius locit, s helyette mértani pontosságú, semleges, absztrakt teret hoz létre.” Ez számomra egy hitalapú mítosz, olyan sehová sem vezetô álvita, ami például a virtuális közösségek „valóságos” közösségekkel szembeni másodlagosságát hirdetőknél is megjelenik. A fizikai térben létező hely misztifikálása kapcsán felháborodottan kérdezném, hogy miért lenne értékesebb az alkoholista házmesterrel való teljesen személytelen kapcsolatom a nyolcadik kerületi gangos házban, csupán azért, mert egy házban lakunk, mint bárkivel, akivel e-mailen kommunikálok (mint például magával Sükösddel). Számomra a helyhez és az értelemhez nem kell feltétlenül fizika és sajnálom azokat, akik ehhez csökönyösen ragaszkodnak.

Azt a logikai ugrást sem értem, ami a genius loci bevezetését követi: „[a]z ökológiai rendszer, a biomassza, a termékeny televény azonban nem az elvont mértani térben, hanem az élőhelyen tenyészik. A két térfelfogás mereven elválik egymástól és ellentétben áll egymással." Eddig a valós társadalmi tér elvesztéséról beszélt Sükösd, most pedig hirtelen természeti térrôl állít dolgokat, pedig a kettő nem ugyanaz! Tisztázzuk, hogy két kettőségrôl beszélhetünk: 1. természet vs. társadalom, 2. (társadalmi) valóság vs. médiavalóság (virtualitás). Megtermékenyítő lehetne tehát bevonni az elemzésbe a „kinn a természetben” koncepcióját, a benn-kinn kettôsségét, ahogy ez a megjelölés a természetet „kint”-nek láttatja, tulajdonképpen idegennek. Erról pedig eszünkbe juthat Hankiss Elemér gondolata, hogy az ember tulajdonképpen mindig is arra törekedett, hogy belakja a világát, miközben olyan hellyé teszi, ahol ô van otthon, a középpontban, merthogy a természet eléggé veszélyes, idegen, külsốdleges. (Hankiss, 1999).

A cikkhez szerintem nagyon kellene tehát a társadalom és a természet közötti viszonyt tisztázó leírás is, amihez remek kiindulópont lehet Bruno Latour „Sohasem voltunk modernek" címú könyvének ide csatlakozó része:

„Első paradoxon

A társadalmat szabadon alakítjuk; cselekedeteinkre nézve immanens.

A természet nem a mi alkotásunk; transzcendens és végtelenül hatalmasabb nálunk. 


\section{Második paradoxon}

A társadalom nem a mi alkotásunk; transzcendens és végtelenül hatalmasabb nálunk.

A természetet mi hozzuk létre mesterséges úton a laboratóriumban; immanens. Harmadik paradoxon

Az elsố garancia: noha mi konstruáljuk a természetet, a természet olyan, mintha nem mi hoznánk létre.

A második garancia: noha mi konstruáljuk a társadalmat, a társadalom olyan, mintha nem mi hoznánk létre.

A harmadik garancia: a természetnek és a társadalomnak teljességgel szétválasztottnak kell maradnia: a purifikáció gyakorlata nem keveredhet a transzláció gyakorlatával." (Latour, 1999: 61)

\section{Befejezés: ki felelős a bűnbeesésért?}

Ökológiai válság van. Az ökológiai válság mélyül. Erről a médiából tájékozódunk, könyvekból, újságokból, rádióból, tévébôl, az Internetrôl... Ugyanakkor ez a média teszi lehetôvé azt is, hogy ritkábban szembesüljünk közvetlen környezetünkkel, kevesebb időt kelljen vagy lehessen eltölteni abban. Az én meglátásom szerint Sükösd csak az állítás második felével ért maradéktalanul egyet, miközben arról, hogy a média révén szerzünk tudomást az ökológiai válság távoli és közelebbi, minket látszólag közvetlenül nem érintő részéről, egyszerűen szisztematikusan elfeledkezik. Fekete-fehér látásmódja nem enged bizonyos jelenségeket integrálni az elméletébe, amelyek pedig hasznosak volnának a világ megértéséhez. Leegyszerúsítései a sokszínűséget, a társadalmi reakciók változatosságát tüntetik el a világot leíró elképzelésből.

Tisztázásra vár specifikusan az írás érvrendszerén belül a média természete is: nemcsak a reklámok eladására épülő üzleti modellben terjeszkedő mainstream kereskedelmi média A Média, hanem a nem kereskedelmi, a nem reklámokra épülő, a nem mainstream média is. Vajon ezekre is igazak az állítások? Nem szól Sükösd - a VR hagymázas vízióját leszámítva - az Internet és az új kommunikációs közeg hatásairól sem, különösen, ami az új társadalmi mozgalmak, köztük a zöld mozgalmak forradalmi megújulását illeti.

Tisztázni kellene azt is, hogy milyen a kapcsolatrendszer a természet és a társadalom, illetve a társadalom és a medialitás között, ezt a kettôs párrendszert ugyanis Sükösd a modernitás hagyományainak megfelelően gyakran egybemossa.

Több mint 6 milliárd ember él a Földön. Az emberiséget már rég nem közvetlenül a természet, hanem az annak kárára múködő társadalmi-gazdasági együttélési rendszer tartja el. Fel kell tennünk a kérdéseket, hogy van-e alternatívája a kapitalista termelési rendszernek? Van-e lehetôség arra, hogy megújuljon ez a rendszer, egyszerre legyen képes eltartani minket és békében együtt élni a természettel? Ezekre a kérdésekre mindannyiunknak, de elsősorban a tudománynak, a mûvészetnek és a vallásnak kellene érvényes válasszal rendelkeznie.

Végül szót kell ejtenünk a felelôsség kérdésérôl is: nem kizárólag a Média, vagy a Média logikája okolható az ökológiai válságnak a médiában látható sajátos társadalmi megjelenéséért. Miért nem megyünk tovább és kérdezünk rá, hogy miért történik 
mindez a médiában, miért így jelennek meg a narratívák, hol van ebben az emberek, a társadalom és ad abszurdum a természet felelőssége? Ha a televízió és a média sátáni, az még nem jelenti feltétlenül azt, hogy bủnbe is kell esnünk vele.

\section{IRODALOM}

Baudrillard, Jean (1994): Az orgia után. (Liget 1994/1, 44-59)

Görgey Gábor (2004): Liszt Ferenc tér. (Figyelő, 2004 május 20-26, 45-ik oldal)

Hankiss Elemér (1999): Az emberi kaland. Egy civilizáció-elmélet vázlata. (Universitas sorozat, Budapest, Helikon Kiadó, 3. kiadás)

Latour, Bruno (1999): Sohasem voltunk modernek. (Budapest, Osiris)

Pintér Róbert (2002): Az információs társadalom mint kockázattársadalom. (Információs társadalom, 2002/4. 102-117)

Pintér Róbert (2003): A hazai médiafogyasztás (át)alakulása az Internet tükrében (Kézirat, megjelenés alatt az Internet.hu második kötetében)

Webster, Frank (1995): What information Society? (The Information Society, Vol. 10(1), 1-23)

Szvetelszky Zsuzsanna - Oborny Beáta - Kertész Miklós: Homo labilis 